\title{
PENERAPAN METODE SIMPLE ADDITIVE SISTEM (SAW) PENDUKUNG KEPUTUSAN SELEKSI PENERIMA BEASISWA PADA SMK N 5 PADANG
}

\author{
Sahari $^{1}$ \\ Syafri Arlis ${ }^{2}$
}

\begin{abstract}
In an institution or organization especially education, would be required a system to support the decision. There is a possibility decision system is also carried out concerned by the levels in the organization. The decision support systems application has designed to help the school management determine to select the students are eligible to receive a scholarship. That's why using a decision support system admission scholarship at the Vocational High School 5 Padang using SAW (Simple Addiitive weighting) method. The method of calculation are going by manually first, then maded a computerized using a web-based application. With hoping this system is expected to reduce the occurrence of errors in the selection of students to get the scholarships of the schools proposed format.
\end{abstract}

Keyword : Scholarship, Simple Addiitive weighting, Decision Support Systems

\section{INTISAR I}

Dalam suatu institusi atau organisasi terutama bergerak di bidang pendidikan, tentu membutuhkan sistem untuk menunjang keputusan. Tidak tertutup kemungkinan sistem pengambilan keputusan juga dilakukan oleh level yang bersangkutan pada organisasi tersebut. Aplikasi sistem pendukung keputusan dirancang untuk membantu pihak manajemen sekolah untuk menentukan memilih siswa yang berhak menerima beasiswa. Hal ini mengakibatkan digunakan sebuah sistem pendukung keputusan penerimaan beasiswa pada SMK N 5 Padang menggunakan metode SAW (Simple Addiitive Weighting). Dimana metode akan dilakukan perhitungan secara manual terlebih dahulu, setelah itu dibuat secara komputerisasi menggunakan aplikasi berbasis web. Dengan adanya sistem ini diharapkan dapat mengurangi terjadinya kesalahan dalam pemilihan siswa berprestasi untuk mendapatkan beasiswa format usulan sekolah.

\section{Kata Kunci : Beasiswa, Simple Addiitive weighting, Sistem Pendukung Keputusan}

\footnotetext{
${ }^{1,2}$ Dosen Universitas Putra Indonesia "YPTK” Padang
} 


\section{PENDAHULUAN}

Dalam menentukan penerima beasiswa, banyak sekali kriteriakriteria yang harus dimiliki oleh siswa sebagai syarat dalam mendapatkan beasiswa. Pada studi kasus kali ini, penghitungan dan penyeleksian penerimaan beasiswa masih dihitung manual. Untuk dapat membantu penentuan dalam menetapkan seseorang yang layak menerima beasiswa, maka dibutuhkan sebuah sistem pendukung keputusan.

Pada SMK Negeri 5 Padang program beasiswa ini sangat membantu siswa siswi yang bersekolah di smk tersebut. Program beasiswa ini digolongkan menjadi dua yaitu beasiswa untuk siswa siswi yang kurang mampu dan beasiswa yang diperuntukkan kepada siswa siswi yang mempunyai prestasi akademik maupun non akademik. Oleh karena itu, Penulis tertarik membangun dan me ngimplementasikan sistem pendukung keputusan seleksi penerima beasiswa menggunakan metode SAW (Simple Additive Weighting), dimana metode tersebut dapat menentukan nilai bobot untuk setiap atribut. Kemudian dilanjutkandengan proses perankingan yang akan menyeleksi alternatif terbaik dari sejumlah alternatif. Dalam hal ini, alternatif yang dimaksud adalah siswa yang berhak menerima beasiswa berdasarkan kriteria-kriteria yang telah ditentukan.

Berdasarkan latar belakang diatas, maka dapat diambil rumusan masalah sebagai berikut :

1. Bagaimana membangun sistem pendukung keputusan seleksi calon penerima beasiswa dapat menghasilkan keputusan yang lebih cepat dan akurat?

2. Bagaimana membangun sistem pendukung keputusan seleksi calon penerima beasiswa dapat mempengaruhi terhadap motivasi belajar siswa?

3. Apakah dengan adanya sistem pendukung keputusan seleksi calon penerima beasiswa dapat meringankan beban keluarga bagi siswa yang kurang mampu?

4. Apakah pihak sekolah merasakan kepuasan dengan adanya sistem pendukung keputusan seleksi calon penerima beasiswa yag akan diterapkan.

\section{PENDEKATAN DAN PEMECAHAN MASALAH}

\section{Konsep Dasar Sistem}

Menurut Tata Sutabri (2012: 2) Terdapat dua kelompok di dalam pendefenisian sistem, yaitu kelompok yang menekankan pada prosedur dan kelompok yang menekankan pada elemen atau komponennya. Suatu sistem terdiri dari unsur-unsur masukan (Input), pengolahan atau proses (Process), dan keluaran berupa hasil (Output).

Suatu sistem dapat terdiri dari sistem-sistem bagian (subsystems). Masing-masing subsistem dapat terdiri dari subsistem-subsistem yang lebih kecil lagi atau terdiri dari komponen-komponen. Subsistem perangkat keras (hardware) dapat terdiri dari alat masukan, alat pemproses, alat keluaran dan simpanan luar. Subsistem-subsistem saling berinteraksi dan saling berhubungan membentuk satu kesatuan sehingga tujuan atau sasaran sistem tersebut dapat tercapai. Interaksi dari subsistemsubsistem sedemikian rupa, sehingga dicapai suatu kesatuan yang terpadu atau terintegrasi (integrated).

\section{Pengertian Sistem}

Menurut Tata Sutabri (2012: 6) Sistem adalah sekelompok unsur yang erat hubungannya satu dengan yang lain, yang berfungsi bersama- 
sama untuk mencapai tujuan tertentu.

Dari definisi ini, menurut Tata Sutabri (2012: 6) pengertian sistem dapat dirinci lebih lanjut, yaitu sebagai berikut :

1. Setiap sistem terdiri dari berbagai unsur. Unsur-unsur suatu sistem terdiri dari subsistem yang lebih kecil yang terdiri pula dari kelompok-kelompok yang membentuk subsistem tersebut.

2. Unsur-unsur tersebut merupakan bagian yang tak terpisahkan dari sistem yang bersangkutan. Unsur-unsur sistem berhubungan satu dengan yang lain dimana sifat serta kerja sama antar unsur dalam sistem tersebut mempunyai bentuk tertentu.

3. Unsur-unsur di dalam sistem tersebut bekerjasama untuk mencapai tujuan sistem. Setiap sistem mempunyai tujuan tertentu.

4. Suatu sistem merupakan bagian dari sistem lain yang lebih besar.

\section{Karakteristik Sistem}

Selain memiliki komponen dan prosedur yang saling berhubungan, sistem juga memiliki karakteristik, Menurut Tata Sutabri (2012: 13) ada beberapa karakteristik sistem, diantaranya :

1. Komponen Sistem (Component) Suatu sistem terdiri dari sejumlah komponen yang saling berinteraksi, yang bekerja sama membentuk satu kesatuan. Komponen-komponen sistem tersebut dapat berupa suatu bentuk subsistem. Setiap subsistem memiliki sifat-sifat sistem yang menjalankan suatu fungsi tertentu dan mempengaruhi proses sistem secara keseluruhan.

2. Batasan Sistem (Boundary)

Merupakan daerah yang membatasi antara sistem yang satu dengan sistem yang lain. Batasan sistem ini memungkinkan suatu sistem dipandang sebagai satu kesatuan yang tidak dapat dipisah-pisahkan.

3. Sasaran Sistem (Objective)

Suatu sistem memiliki tujuan dan sasaran yang pasti dan bersifat deterministik. Kalau suatu sistem tidak memiliki sasaran, maka operasi sistem tidak ada gunanya. Suatu sistem dikatakan berhasil bila mengenai sasaran atau tujuan yang telah direncanakan.

\section{Siklus Hidup Pengembangan Sistem}

Menurut Rosa A.S. M. Shalahuddin (2013: 26) SDLC atau System Development Life Cycle adalah proses mengembangkan atau mengubah sistem perangkat lunak dengan menggunakan modelmodel dan metodologi yang digunakan untuk mengembangkan sistem perangkat lunak sebelumnya.

Fase-fase yang ada pada SDLC adalah sebagai berikut :

1. Identifikasi dan Seleksi Proyek Dalam tahap ini ada beberapa hal yang harus dilakukan, di antaranya mengidentifikasi proyek potensial, melakukan klasifikasi dan merangking proyek dan memilih proyek untuk dikembangkan.

2. Insiasi dan Perencanaan Proyek Ditentukan secara detail rencana kerja yang dikerjakan, durasi yang diperlukan pertahap, sumber daya manusia, perangkat lunak dan keras, maupun financial diestimasi.

\section{Konsep Sistem Pendukung Keputusan}

Menurut jurnal (Sri Eniyati : 2011) Sistem pendukung keputusan adalah sistem penghasil informasi yang ditujukan pada suatu masalah tertentu yang harus dipecahkan oleh manager dan dapat membantu manager dalam pengambilan 
keputusan (Raymond Mc Leod, Jr., 1995:348).

Tujuan dari keputusan adalah untuk mencapai target atau aksi tertentu yang harus dilakukan (Kusrini, 2007:7).

Menurut jurnal (Sri Eniyati :2011) tentang Perancangan Sistem Pendukung Keputusan untuk penerima beasiswa dengan metode SAW, untuk menghasilkan keputusan yang baik didalam sistem pendukung keputusan, perlu didukung oleh informasi dan faktafakta yang berkualitas antara lain :

a. Aksebilitas, yaitu atribut yang berkaitan dengan kemudahan mendapatkan informasi. Informasi tersebut lebih berarti bagi si pemakai kalau mudah didapatkan.

b. Kelengkapan, yaitu berkaitan dengan isi informasi. Dalam hal ini juga menyangkut dengan harapan si pemakai.

\section{Defenisi Sistem Pendukung Keputusan}

Sistem Pendukung Keputusan (SPK)/ Decision Support System (DSS) adalah sistem informasi interaktif yang menyediakan informasi,pemodelan, dan pemanipulasian data. Sistem itu digunakan untuk membantu pengambilan keputusan dalam situasi yang semi terstruktur dan situasi yang tidak terstruktur, dimana tak seorang pun tahu secara pasti bagaimana keputusan itu dibuat (Kusrini, 2007:15).

\section{Landasan Hukum Beasiswa.}

Pada dasarnya, beasiswa adalah penghasilan bagi yang menerimanya.Hal ini sesuai dengan ketentuan pasal 4 ayat (1) UU $\mathrm{PPh} / 2000$. Pengertian penghasilan adalah tambahan kemampuan ekonomis dengan nama dalam bentuk apapun yang diterima atau diperoleh dari sumber Indonesia atau luar Indonesia yang dapat digunakan untuk konsumsi atau menambah kekayaan Wajib Pajak (WP). Karena beasiswa bisa diartikan menambah kemampuan ekonomis bagi penerimanya, berarti beasiswa merupakan penghasilan. (Rita Mustika,2009).

\section{FMADM}

FMADM (Fuzzy Multiple

Atribut Decision Making) adalah suatu metode yang digunakan untuk mencari alternatif optimal dari sejumlah alternatif dengan kriteria tertentu. FMADM merupakan penentuan nilai bobot untuk setiap atribut, dilanjutkan dengan proses perangkingan yang akan menyeleksi alternatif yang sudah diberikan. (Jurnal, Yusmawati).

Ada beberapa metode yang dapat digunakan untuk menyelesaikan masalah FMADM :
a. Simple Additive Weighting (SAW)
b. ELECTREE
c. TOPSIS
d. Analytical Hierarcy Process (AHP)

\section{Konsep Metode Simple Additive Weighting}

Metode SAW sering juga dikenal sebagai istilah metode penjumlahan terbobot.Konsep dasar metode SAW adalah mencari penjumlahan terbobot dari rating kinerja pada setiap alternatif pada semua atribut.

Metode SAW membutuhkan proses normalisasi matriks keputusan $(X)$ ke suatu skala yang dapat diperbandingan dengan semua rating alternatif yang ada. (Rita Mustika,2009).

\section{Alat Bantu Perancangan Sistem}

Dalam perancangan suatu sistem informasi, dibutuhkan beberapa alat bantu perancangan sistem agar analisa dan hasil yang ingin dicapai dapat mencapai sebuah hasil maksimal. Dalam 
melakukan perancangan aplikasi ini ada alat bantu yang digunakan dalam perancangan sistem yang akan dibuat agar tujuan dari penelitian serta pembahasan lebih terarah.

\section{Unified Modeling Language (UML)}

Pada perkembangan teknologi perangakt lunak, diperlukan adanya bahasa yang digunakan untuk memodelkan perangkat lunak yang akan dibuat dan perlu adanya standarisasi agar orang diberbagai negara dapat mengerti pemodelan perangkat lunak, seperti yang kita ketahui bahwa menyatukan banyak kepala untuk menceritakan sebuah ide dengan tujuan untuk memahami hal yang sama tidaklah mudah, oleh karena itu diperlukan sebuah pemodelan perangkat lunak yang dapat dimengerti oleh banyak orang.

\section{ANALISA DAN PERANCANGAN SISTEM}

\section{Analisa Sistem Yang Sedang Berjalan}

Demi memperoleh sebuah aplikasi pendukung keputusan yang dapat mewakili sistem yang lama, memperbaiki serta melakukan tinjauan evaluasi, maka dilakukan analisa terhadap sistem yang lama yang masih menggunakan perhitungan manual.

\section{Analisa Input, Proses, Output} Dalam menetapkan siapa saja siswa yang akan menerima beasiswa format usulan sekolah, tim guru BK masih melakukan penghitungan dengan cara manual dan masih mengentrikan data dalam Ms. Excel untuk input data siswa yang membutuhkan waktu yang sangat lama.

Dari hasil analisa, dapat disimpulkan bahwa sistem masih belum terkomputerisasi pada proses penetapan penerima beasiswa. Maka dari itu, perlu dikembangkan sebuah aplikasi untuk mendukung pengambilan keputusan sehingga tidak akan membutuhkan waktu yang sangat lama.

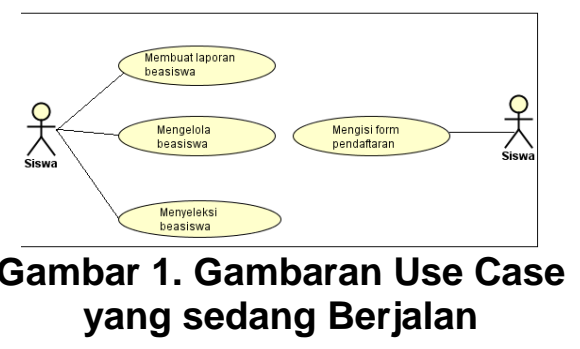

\section{Analisa Proses Rumus Dan Langkah-Langkah SAW}

Dalam perhitungan SAW ini, komponen utamanya adalah struktur hirarki sebagai persepsi awal. Proses akan beranjut pada pembobotan kriteria yang akan mempengaruhi semua elemen berikutnya.

Pada dasarnya, langkahlangkah dalam metode SAW adalah sebagai berikut :

1. Mengidentifikasi Masalah

2. Struktur Hirarki

3. Menentukan nilai bobot berdasarkan prioritas

4. Melakukan Pembobotan pada setiap kriteria

5. Membuat tabel daftar calon penerima beasiswa

6. Mengidentifikasi vektor bobot $\mathrm{W}$ dan matrik keputusan $X$

7. Melakukan normalisasi terhadap matrix X

8. Menentukan hasil akhir $\mathrm{V}$ dari perkalian $(R \times W)$ dengan baris dikali kolom.

\section{Perancangan Sistem baru}

Perancangan sistem adalah merancang atau mendesain suatu sistem yang baik, yang isinya adalah langkah-langkah operasi dalam proses pengolahan data dan prosedur untuk mendukung operasi sistem. 


\section{Unified Modeling Language (UML) Use case Diagram}

$$
\text { Use case Diagram, }
$$
menggambarkan sekelompok Use cases dan aktor yang disertai dengan hubungan diantaranya. Use case diagram dapat sangat membantu bila kita sedang menyusun requirement sebuah sistem, mengkomunikasikan rancangan dengan klien dan merancang test case untuk semua feature yang ada pada sistem.

Sebuah use case dapat menginclude fungsionalitas use case lain sebagai bagian dari proses dalam dirinya. Secara umum diasumsikan bahwa use case yang di-includeakan dipanggil setiap kali use case yang meng-include dieksekusi secara normal.Adapun use case diagram dari sistem pendukung keputusan SMK N 5 Padang, dapat digambarkan seperti Gambar dibawah ini :

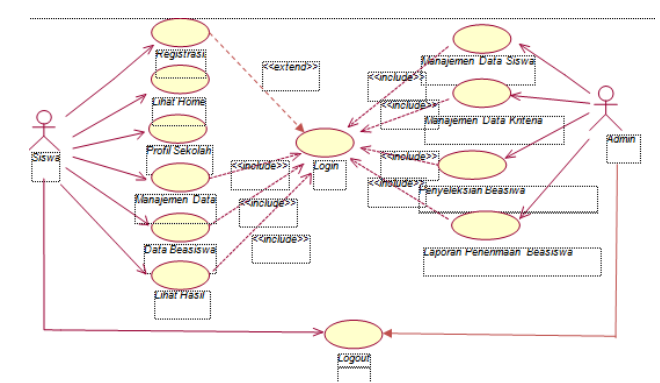

\section{Gambar 2. Use Case Diagram Sistem Pendukung Keputusan Penerimaan Beasiswa}

\section{Class Diagram}

Class diagram menampilkan eksistensi atau keberadaan dari class-class dan hubungan (relationship) dalam desain logikal dari sebuah sistem.Class adalah sebuah spesifikasi yang jika diinstansiasi akan menghasilkan sebuah objek dan merupakan inti dari pengembangan dan desain berorientasi objek. Class menggambarkan keadaan (atribut/properti) suatu sistem, sekaligus menawarkan layanan untuk memanipulasi keadaan tersebut (metoda/fungsi).

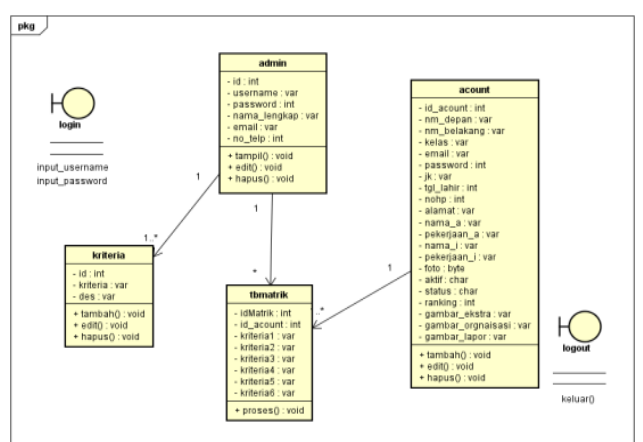

Gambar 3. Class Diagram SistemPendukung Keputusan

\section{HASIL DAN PEMBAHASAN}

\section{Implementasi Sistem}

Implementasi merupakan tahap merepresentasikan hasil desain ke dalam pemrograman.Sedangkan, sistem merupakan kumpulan dari elemenelemen yang berinteraksi untuk mencapai suatu tujuan tertentu.Implementasi Sistem merupakan kumpulan dari elemenelemen yang telah didesain kedalam bentuk pemograman untuk menghasilkan suatu tujuan yang dibuat berdasarkan kebutuhan.

\section{Pengujian Program}

Bagian Home pada menu utama menjelaskan kata pengantar sebelum memulai aksi-aksi seperti registrasi dan penilaian serta aksi lainnya.

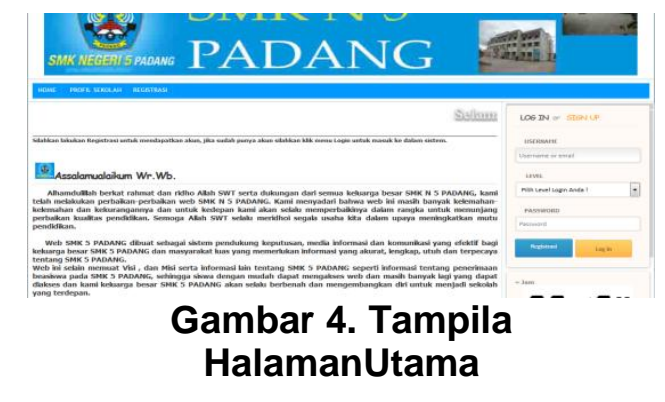




\section{Desain Input}

Adapun tujuan penting mendesain input adalah untuk menangkap dan mengubah data kedalam format yang sesuai pada komputer.Bagus atau tidaknya output yang dihasilkan tergantung pada input data yang dimasukkan. Desain input mencakup semua masukkan yang terjadi sebagai bahan untuk pengolahan.

\section{Tampilan Registrasi Akun}

Data registrasi beasiswa disimpan didalam database beasiswa pada tabel acount.Pada tampilan ini, siswa atau user harus melakukan registrasi terlebih dahulu.

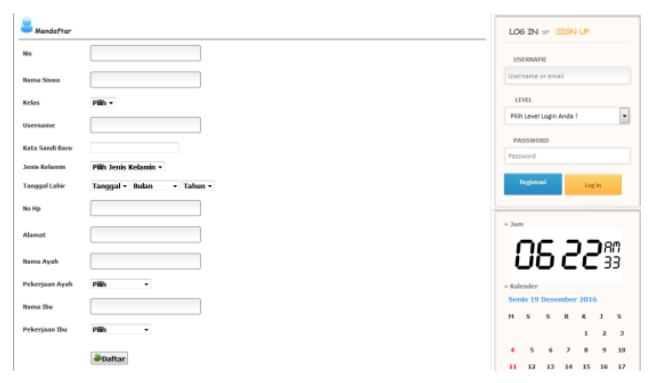

\section{Gambar 5. Tampilan Registrasi}

\section{Tampilan Menu Login}

Form login merupakan tampilan yang harus di masuki oleh guru/ admin dan siswa yang telah melakukan registrasi agar dapat mengolah data yang akan di calonkan untuk penerimaan beasiswa FUS (Format Usulan Sekolah).
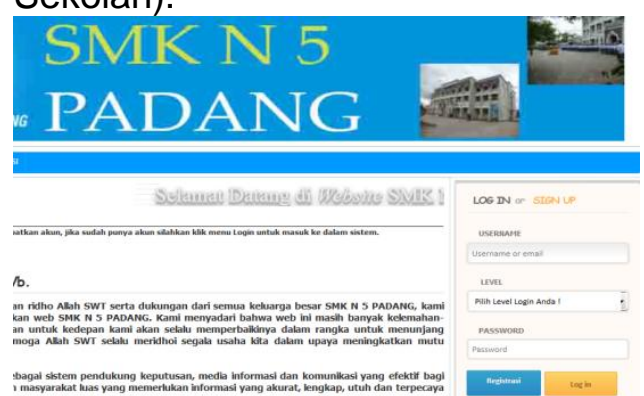

Gambar 6. Menu Login Menu Manajemen Data

Adapun menu manajemen
data pada Sistem Pendukung
Keputusan yang telah dirancang,

Siswa dapat melakukan update data jika ada yang salah sebelum proses pencetakan oleh admin.

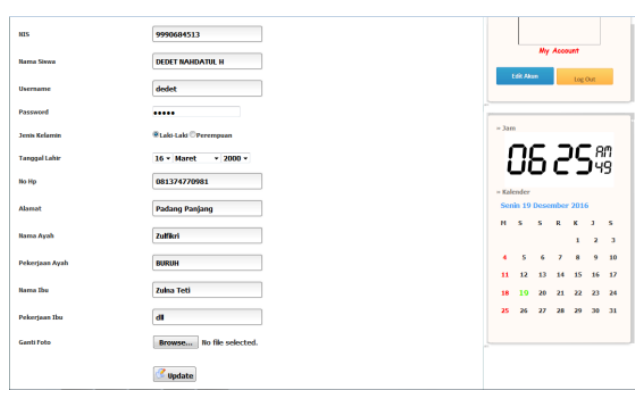

\section{Gambar 7. Menu Edit Data}

\section{Menu Data Beasiswa}

Pada menu data beasiswa, bagi siswa terlihat tampilan data kriteria yang harus diisi oleh siswa pendaftar.

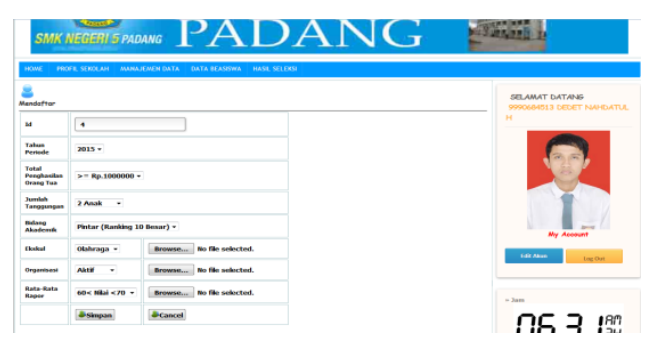

\section{Gambar 8. Input Data Beasiswa Hasil Seleksi}

Apabila data beasiswa sudah diproses oleh admin, maka bagi para siswa yang berhak menerima beasiswa akan mendapatkan pesan dari admin pada halaman ini. Untuk lebih jelasnya, tampilan hasil seleksi dapat dilihat pada Gambar 9 :

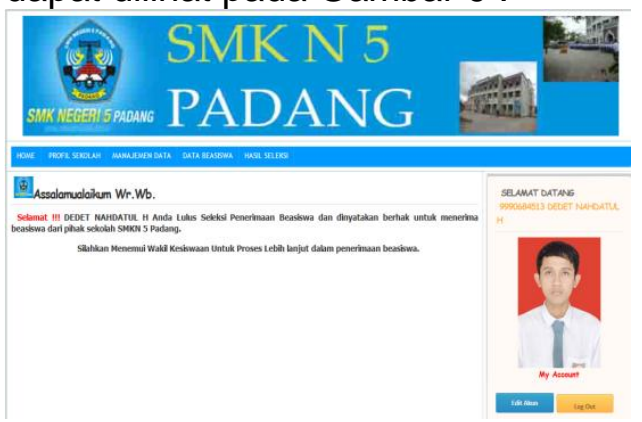

\section{Gambar 9. Pesan Hasil Seleksi Tampilan Data Siswa}


Setelah siswa berhasil login dan mengisi data-datanya, admin melakukan login dan melihat siapa saja yang sudah melakukan registrasi. Pada tampilan data siswa, admin dapat melihat data siswa dan menghapus data yang masih salah.

Tampilan data siswa menyerupai seperti laporan data siswa yang menyediakan field nomor, nama siswa, kelas, jenis kelamin, alamat, pekerjaan ayah dan ibu berdasarkan tabel acount.

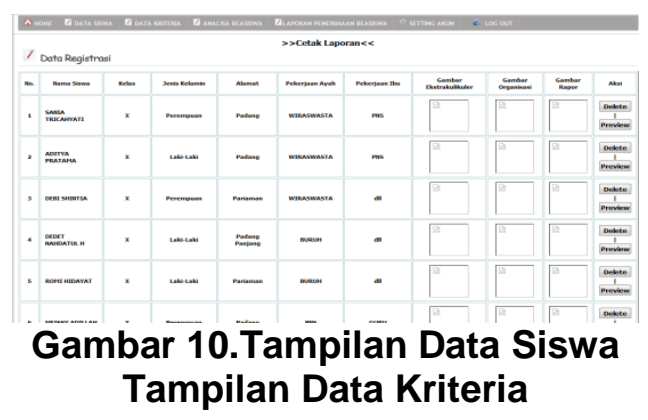

Data kriteria merupakan
bagian yang sama pentingnya
dengan yang lain. Kriteria yang
dibutuhkan dalam proses
penghitungan beasiswa sangat
mempengaruhi hasil akhirnya.
Tampilan data kriteria yang
disimpan didalam database
beasiswa pada tabel krteria.

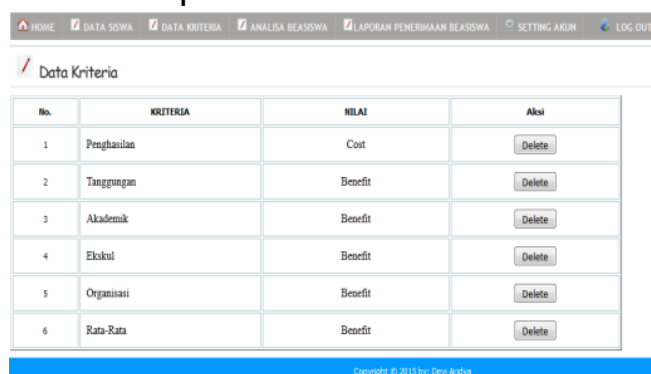

Gambar 12.Tampilan Data Kriteria

\section{Tampilan Hasil Analisa}

Menjelaskan hasil analisa mulai dari identifikasi matriks $X$, matriks $\mathrm{R}$ awal dan hasil akhir matriks $R$. setelah seleuruh data disimpan, admin bisa mencetak laporan siapa saja yang menerima beasiswa.

Pada database, tabel matrik digunakan untuk melakukan perhitungan dimana telah dihitung menggunakan rumus sebelumnya.

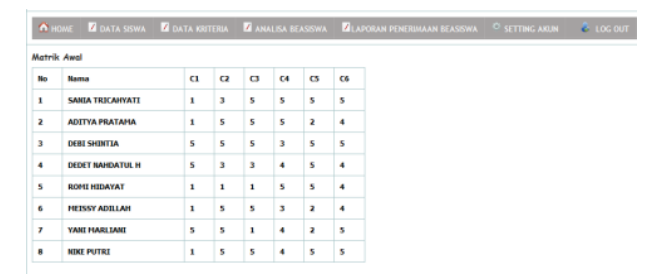

Gambar 12. Matriks awal $X$

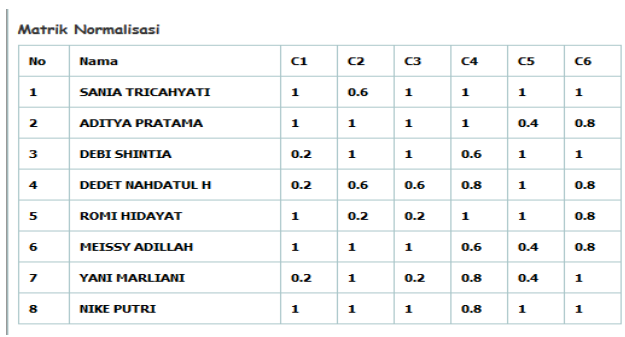

Gambar 13. Matriks R

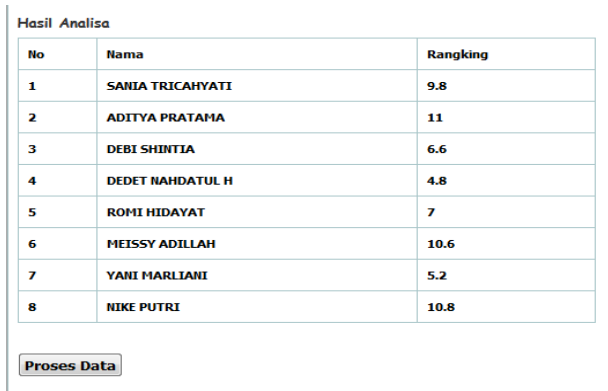

\section{Gambar 14. Hasil Akhir Matriks}

\section{Menu Laporan}

Menu laporan menampilkan hasil akhir lulus atau tidak lulusnya siswa dalam mendapatkan beasiswa format usulan sekolah berdasarkan kriteria-kriteria yang telah di tentukan

\section{Laporan Penerimaan Beasiswa}

Laporan beasiswa pada
Sistem Pendukung Keputusan
Penerimaan Beasiswa menampilkan
hasil yang akan di informasikan oleh
Guru. Untuk lebih jelasnya, laporan
beasiswa dapat dilihat pada Gambar
14.




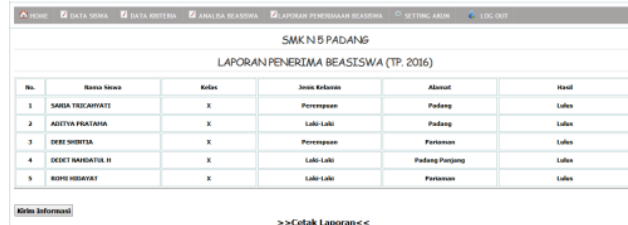

Gambar 14. Laporan

Penerimaan Beasiswa

Laporan Beasiswa Yang Tidak

Terpilih

Laporan beasiswa pada Sistem Pendukung Keputusan Penerimaaan Beasiswa Yang Tidak Terpilih menampilkan hasil yang akan digunakan oleh Guru. Untuk lebih jelasnya, dapat dilihat pada Gambar 15:

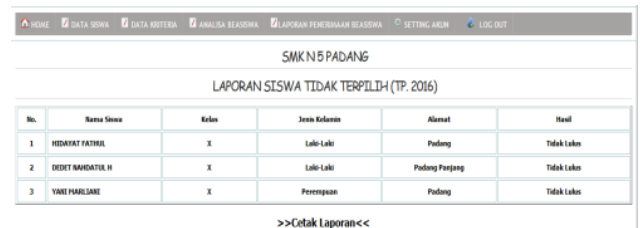

Gambar 15. Laporan Penerimaan Beasiswa Yang Tidak Terpilih

\section{KESIMPULAN}

Sebagaimana yang telah
dijelaskan pada r bab-bab
sebelumnya dan kemudian
dilanjutkan dengan pembahasan
masalah serta berdasarkan hasil
yang didapat dari penelitian sistem
pendukung keputusan penerimaan
beasiswa pada SMK N 5 Padang
menggunakan metode SAW (Simple
Additive Weighting), maka dapat
diambil beberapa kesimpulan
sebagai berikut:

1. Dengan adanya sistem pendukung keputusan penerimaan beasiswa format usulan sekolah ini, diharapkan dapat meningkatkan informasi dan aksebilitas pada SMA N 5 Padang.

2. Dengan menggunakan website yang memanfaatkan bahasa pemrograman PHP diharapkan akan memberi suatu kemudahan bagi siswa dalam mendaftarkan diri untuk menerima beasiswa maupun memberikan kelengkapan data kepada admin supaya dapat melakukan perhitungan dengan mudah dan cepat.

3. Dengan aplikasi sistem pendukung keputusan berbasis web ini, diharapkan Guru sebagai admin dapat dengan mudah mengolah dan memeriksa data siswa sebelum analisa akhirnya dicetak dan diumumkan dengan akurat.

4. Bahasa pemrograman PHP mampu membuat sistem menjadi lebih baikdan diharapkan akan memberi suatu kemudahan bagi guru untuk melakukan perhitungan secara cepat dan analitis, serta memberi kemudahan bagi siswa untuk berkesempatan mendapatkan beasiswa format usulan sekolah tanpa terhalang oleh waktu dan jarak karena dapat dilakukan dimana saja dan kapan saja.

\section{DAFTAR PUSTAKA}

[1] Abdul, Kadir, 2010, "Mudah Mempelajari Database MySQL". Yogyakarta: Andi Offset.

[2] Candra, Surya, "Sistem Pendukung Keputusan Rekomendasi Penerima Beasiswa Menggunakan Fuzzy Multi Attribut Decision Making (FMADM) dan Simple Additive Weighting (SAW)".4 Agustus 2015.

[3] Indrajani S.Kom,MM, 2014, "Database Systems Case Study All in One".Jakarta: Penerbit PT Elex Media Komputindo. 
[4] Kusrini, M.Kom, 2007, "Konsep dan Aplikasi Sistem Pendukung Keputusan". Yogyakarta: Penerbit Andi Offset.

[5] Madcoms, 2008, "Membangun Website dengan HTML, PHP, dan MySQL".Madiun: Penerbit Andi Offset.

[6] Natasya, Mulyono, "Sejarah Perkembangan PHP".15 Desember 2010.

[7] Rita, Mustika, "Perancangan Sistem Pendukung Keputusan Penerimaan Beasiswa dengan Metode SAW (simple additive weighting) di STMIK Pringsewu".20 April 2009.

[8] Rosa A.S, M.Shalahuddin. 2013. "Rekayasa Perangkat Lunak". Bandung: Penerbit Informatika.

[9] Sri Erniyati, "Perancangan Sistem Pendukung Pengambilan Keputusan Untuk Penerimaan Beasiswa dengan Metode SAW (Simple Additive Weighting)".2 Juli 2011.

[10] Tata, Sutabri, 2012, "Analisis \& Perancangan Sistem Informasi".Yogyakarta:

Penerbit Andi Offset.

[11] Wahana, Komputer, 2011, "Mastering CMS programming with PHP \& MySQL". Semarang: Penerbit Wahana Komputer. 